\title{
REFERENCES
}

Bland, M. N., Constable, B. J., Harris, L. J. \& Hughes, R. E. (1952a). Biochem. F. 5I, xxxv.

Bland, M. N., Constable, B. J., Harris, L. J. \& Hughes, R. E. (r952b). Congr. int. Biochim. 2. Paris, p. 325 .

Clayton, B. E. \& Prunty, F. T. G. (195 I). Brit. med. J. ii, 927.

Constable, B. J., Harris, L. J. \& Hughes, R. E. (1955). Proc. Nutr. Soc. 14, x.

Eisenstein, A. B. \& Shank, R. E. (1951). Proc. Soc. exp. Biol., N. Y., 78, 619.

Fish, E. W. \& Harris, L. J. (1934). Phil. Trans. B, 223, 489.

Harris, L. J., Bland, M. N., Hughes, R. E. \& Constable, B. J. (1953). Lancet, 264, ro2 I.

Harris, L. J., Mills, I. \& Innes, J. R. M. (1932). Lancet, 223, 235.

Harris, L. J. \& Olliver, M. (1942). Biochem. F. 36, 155.

Harris, L. J. \& Ray, S. N. (1932). Biochem. F. 26, 2067.

Harris, L. J. \& Ray, S. N. (I933a). Biochem. F. 27, 303 .

Harris, L. J. \& Ray, S. N. (1933b). Biochem. F. 27, 2006.

Höjer, J. A. \& Westin, G. (1925). Dent. Cosmos, 67, r.

Hughes, R. E., Harris, L. J., Constable, B. J. \& Bland, M. N. (1952). Biochem. 7. 5I, xxxv.

Hyman, G. A., Ragan, C. \& Turner, J. C. (1950). Proc. Soc. exp. Biol., N.Y., 75, 470.

Key, K. M. \& Elphick, G. K. (I93 I). Biochem. Y. 25, 888.

Mindlin, R. L. \& Butler, A. M. (1937). J. biol. Chem. 122, 673.

Sayers, G., Sayers, M. A., Lewis, H. L. \& Long, C. N. H. (1 944). Proc. Soc. exp. Biol., N. Y., 55, 238.

Szent-Györgyi, A. (1928). Biochem. F. 22, 1387 .

\section{Physiological Undernutrition in the Newborn Guinea-pig}

\author{
By ELSIE M. WIDDOWSON AND R. A. MCCANCE \\ Medical Research Council Department of Experimental Medicine, \\ University of Cambridge \\ (Received 26 March 1955)
}

Physiological undernutrition is a phase in the natural development of some animals. The Atlantic seal is probably the most dramatic example of it among the mammals, for, after a short period of suckling and the deposition of fat in large quantities, the young of this species spend the next few weeks of their lives starving on the beach (Darling, I 947; Amoroso, Goffin, Halley, Matthews \& Mathews, 195I). Only after this period of starvation do they take to the sea in search of their own food. Some of the sea birds go through a similar series of nutritional ups and downs, which have been even less studied than those of the seal. Puppies and kittens may get fat during suckling, only to lose much of the fat when they are weaned, and the human infant has a short period of physiological undernutrition from the moment of birth till the flow of milk is established.

In the course of some work on the chemistry of growth, observations made on the newborn guinea-pig suggested that the animal must pass through a period of physiological undernutrition in the ist week of its life. Since the observations appeared not to have been previously described, it was decided to use this convenient laboratory animal for a study of the effects of a naturally induced undernutrition on the composition of the body. The cause of the undernutrition would seem to be that the 
guinea-pig is so mature when it is born that it never lives entirely on its mother's milk, but begins to eat other food straight away. In other words, it begins to be weaned as soon as it is born.

\section{EXPERIMENTAL}

Seventeen litters of guinea-pigs, comprising thirty-nine animals, have been used for this investigation. The animals in ten litters were killed at birth and the remainder when they were I week old. The mothers were reared and fed in the laboratory on the stock diet of sugar-beet pulp, bran, oats and greens, and the sixteen young not killed at birth were allowed free access to this food. As the number in the litter makes a considerable difference to the size of the newborn animal, those to be killed when they were a week old were taken from litters similar in size to those from which animals had been taken at birth. Litters of one, two and three were used; all the animals in any one litter were taken at the same time and their bodies were pooled for analysis. Livers were analysed separately from the rest of the body. A sample of blood was taken and the serum separated for the determination of chloride. The methods of sampling for analysis and chemical techniques were those described by Spray \& Widdowson (195I), and Harrison (1953 $a, b$ ), except that sodium and potassium were determined with a Beckman flame photometer.

\section{RESULTS}

Table I shows the average composition of the bodies (excluding the livers) of the guinea-pigs killed at birth and of those killed I week after birth. The I-week-old animals were only $20 \mathrm{~g}$ heavier than those killed at birth, but they were considered to be doing well. They contained, however, less fat, both absolutely and as percentages

\section{Table I. Mean weight and composition, with their standard errors, of the bodies} of litters of guinea-pigs at birth and at the age of I week

\begin{tabular}{|c|c|c|}
\hline & At birth & At I week \\
\hline $\begin{array}{l}\text { No. of litters } \\
\text { No. of animals } \\
\text { Weight of one animal (g) }\end{array}$ & $\begin{array}{l}\text { 10 } \\
23 \\
94 \pm 6 \cdot 4\end{array}$ & $\begin{array}{ll} & 7 \\
& I 6 \\
114 & \pm I I \cdot x\end{array}$ \\
\hline 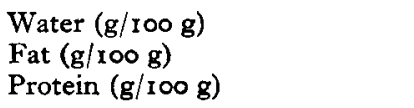 & $\begin{array}{ll}69 \cdot 3 \pm & 1 \cdot 2 \\
10 \cdot 4 \pm & 0.85 \\
16 \cdot 1 \pm & 0.88\end{array}$ & $\begin{array}{l}75.0 \pm 1.7 \\
2.5 \pm 0.50 \\
16.6 \pm 0.40\end{array}$ \\
\hline  & $\begin{array}{l}18 \cdot 2 \pm 0.54 \\
163 \pm 5 \cdot 9 \\
268 \pm 3 \cdot 7 \\
1231 \pm 43 \cdot 6 \\
46 \cdot 1 \pm 1 \cdot 88 \\
752 \pm 21.8\end{array}$ & $\begin{array}{r}17 \cdot 1 \pm 0 \cdot 20 \\
141 \pm 4 \cdot 8 \\
260 \pm 9 \cdot 6 \\
1050 \pm 31 \cdot 8 \\
44 \cdot 8 \pm 2 \cdot 01 \\
670 \pm 20 \cdot 2\end{array}$ \\
\hline Ratio, N:K & II.0 0.08 & $10.5 \pm 0.52$ \\
\hline
\end{tabular}

of their body-weights, and the percentage of water was higher. The percentage of protein was a little higher, but this difference was reversed in terms of fat-free tissue. On a fat-free basis there was a somewhat smaller concentration of $\mathrm{Na}$, which represents the normal developmental change in the extracellular fluids. Although the 
changes in protein and $\mathrm{K}$ were both small, they resulted in a fall in the $\mathrm{N}: \mathrm{K}$ ratio. The concentrations of both calcium and phosphorus were lower at the age of $I$ week than they had been at birth.

Table 2. Mean weight and composition, with their standard errors, of the livers of litters of guinea-pigs at birth and at the age of $\mathrm{I}$ week

No. of litters

No. of animals

Weight of liver: $g$ as percentage body-weight

Water $(\mathrm{g} / \mathrm{I} 00 \mathrm{~g})$

Fat $(\mathrm{g} / \mathrm{1} 00 \mathrm{~g})$

Glycogen (g/100 g)

Protein $(g / 100 \mathrm{~g})$

Deoxyribonucleic acid $(\mathrm{g} / \mathrm{r} / 0 \mathrm{~g})$

Protein (g/100 g fat-free tissue)

$\mathrm{Na}$ (mg/roo g fat-free tissue)

$\mathrm{K}$ (mg/roo $\mathrm{g}$ fat-free tissue)

$\mathrm{Cl}$ (mg/roo g fat-free tissue)

Total P (mg/roo g fat-free tissue)

Ratio, N:K

At birth
10
23
$4.90 \pm 0.58$
$5.2 \pm 0.33$
$65.8 \pm 0.94$
$13.4 \pm 0.55$
$6.5 \pm 1.17$
$12.1 \pm 1.00$
$0.12 \pm 0.011$
$14.0 \pm 1.07$
$215 \pm 10.5$
$282 \pm 6.2$
$121 \pm 9.0$
$255 \pm 19.7$
$7.9 \pm 0.35$

At I week

\begin{tabular}{|c|c|}
\hline & $\begin{array}{r}7 \\
16\end{array}$ \\
\hline 3.76 & \pm 0.50 \\
\hline $3 \cdot 3$ & \pm 0.26 \\
\hline $7 I \cdot 8$ & $\pm 1 \cdot 28$ \\
\hline $5 \cdot 2$ & \pm 0.65 \\
\hline $2 \cdot 75$ & \pm 0.38 \\
\hline $\begin{array}{l}17 \cdot 8 \\
0.206\end{array}$ & $\begin{array}{l} \pm 0.53 \\
\pm 0.015\end{array}$ \\
\hline $18 \cdot 8$ & \pm 0.54 \\
\hline 148 & $\pm 13 \cdot 5$ \\
\hline 310 & \pm 18.0 \\
\hline $\begin{array}{l}109 \\
340\end{array}$ & $\begin{array}{l} \pm 10.8 \\
\pm 17.3\end{array}$ \\
\hline & $\pm \quad r .28$ \\
\hline
\end{tabular}

Table 3. Mean mass of the diploid liver cell of guinea-pigs and of some of its contents at birth and at the age of I week

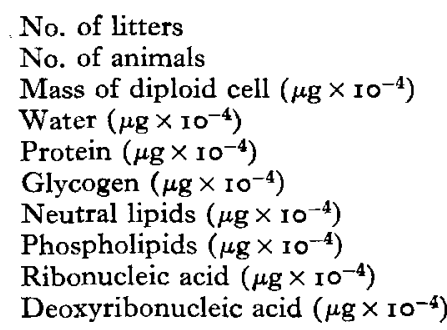

$\begin{array}{cc}\text { At birth } & \text { At r week } \\ 4 & 5 \\ 8 & 13 \\ 37.5 & 22.5 \\ 20.5 & 14.6 \\ 6.16 & 5.25 \\ 3.70 & 0.82 \\ 6.77 & 1.12 \\ 0.79 & 0.66 \\ 0.26 & 0.24 \\ 0.06 & 0.06\end{array}$

Table 2 shows the average composition of the livers. The figure of $13.4 \%$ fat at birth agrees with the findings of Imrie \& Graham (1920), who followed the deposition of fat in the livers of guinea-pigs during gestation. The percentages of glycogen and fat were considerably lower at I week of age, that of water higher and of protein much higher than they were at birth. In terms of fat-free tissue there was a considerable fall in the concentration of $\mathrm{Na}$ and an increase in the concentration of $\mathrm{K}$. The fall in concentration of $\mathrm{Cl}$ was very much less than the corresponding change in $\mathrm{Na}$.

Table 3 shows the mass of the liver cell and the weight of its contents, calculated as described by Harrison (I953a,b). The cells became smaller during the Ist week of the guinea-pig's life, owing largely to a loss of water, glycogen and neutral lipids. There was no significant change in the amount of ribonucleic acid. 


\section{DISCUSSION}

The gross differences in the composition of its body make it clear that the ist week of life is a lean period for the young guinea-pig. The certain signs of undernutrition are the loss of fat and the increase in the percentage of water. Guinea-pigs are among the few species of mammals born with a store of fat (Widdowson, 1950), and the physiological advantages of this are revealed by these experiments. To appreciate the significance of the figures shown in Table $I$ it is, however, important to remember that the animals were not only undernourished but growing. If, for example, it be assumed that the animals killed $\mathrm{r}$ week after birth had the composition at birth of the animals killed when they were born, then the figures show that in the Ist week of life there had been only a small, if a real, increment of protein and that there had actually been a fall when it was expressed per unit weight of fat-free tissue. An unusually high proportion-about $90 \%$ - of the gain in weight had been water and the figures for $\mathrm{Na}$ and $\mathrm{K}$ suggest that this water was in the cells. In other words, a unit weight of cells contained more fluid and less protein than it had done at birth. McCance $\&$ Widdowson (1955) pointed out that during foetal and postnatal life there was a rise in the $\mathrm{N}$, the $\mathrm{K}$ and the $\mathrm{N}: \mathrm{K}$ ratio of the body, and it is now known from work still to be published that this is mainly due to a change in the $\mathrm{N}: \mathrm{K}$ ratio of the skeletal muscle. In these guinea-pigs there was a tendency for the concentration of $\mathrm{N}$ and $\mathrm{K}$, and the $\mathrm{N}: \mathrm{K}$ ratio to fall in the body as a whole, not to rise. This indicates that the changes to be expected as a result of growth were reversed during the first few days after birth. It is possible that the fall in the $\mathrm{N}: \mathrm{K}$ ratio that has been observed in the guinea-pig is due to undernutrition, but a similar fall has been observed in rats and rabbits at this time of life (Dickerson, unpublished observations), and these animals are probably not undernourished. The whole question of the effect of undernutrition and development on the $\mathrm{N}: \mathrm{K}$ ratio is under investigation. The changes in calcium and phosphorus indicate that, although the increase in body-weight had been small, the absorption and retention of $\mathrm{Ca}$ and $\mathrm{P}$ had not kept pace with it.

A fall in the weight of the liver is one of the well-known results of starvation and undernutrition. In adult rats and rabbits, however, it has been usual to find that starvation increased the percentage of fat in the liver, particularly in the first days of the fast or if the animal had previously been well nourished (Dible, I932; Monaghan, 1932; Sinclair, 1933; Dible \& Libman, 1934; Harrison, 1953b). Ohta (r940) found that a rise in the external temperature enhanced this effect and a fall decreased it. The sheep has been rather carefully investigated, particularly during pregnancy, although not on a large total number of animals (Roderick, Harshfield \& Hawn, I937; Wallace, 1948; Ferguson, 1954). A change from a high to a low plane of nutrition at this time may induce severe ketosis and a considerable rise in the percentage of fat in the liver. Speaking generally, the effects of starvation have been studied more extensively than those of undernutrition, and little or no work has up to now been done on newborn animals. A fall in the percentage of fat in the liver may be the usual result of undernutrition at this age, or it may occur because the response of the newborn guinea-pig to undernutrition is unlike that of the adult sheep (Wallace, 1948). 
It is to be noted in this connexion that the percentage of fat in the livers of these newborn guinea-pigs was high and offered scope for a fall, whereas the percentage of fat in an adult rat's liver is usually very much lower. Harrison (1953 $b$ ) found only $0.6-1 \cdot 5 \%$ of neutral lipids.

The figures obtained by the analysis of the liver show that there was a loss of glycogen and fat, which resulted in a decrease in the size of the liver cell. There was a small increase in the total protein in the liver as a whole (from 0.59 to $0.67 \mathrm{~g}$ ), but a greater increase in the deoxyribonucleic acid (from 5.9 to $7.8 \mathrm{mg}$ ), which indicates that the decrease in the size of the cells was brought about not only by their loss of glycogen and fat but also by an increase in their number.

The fact that there was a greater loss of $\mathrm{Na}$ than of $\mathrm{Cl}$ from the liver suggests that some of this $\mathrm{Na}$ may have been coming from the cells. Nevertheless there seems to have been a greater increase in the liver $\mathrm{N}$ than in the liver $\mathrm{K}$, leading to a rise in the $\mathrm{N}: \mathrm{K}$ ratio. As a metabolic organ the liver seems to differ so much from the muscles and other tissues together making up the rest of the body that undernutrition has a very different effect upon its chemical structure, at any rate in the newborn guinea-pig.

These changes in the composition of the newborn guinea-pig are probably similar in principle if not in detail to those going on in the human infant during the first $48 \mathrm{~h}$ of its life.

\section{SUMMARY}

I. Guinea-pigs increase little in weight during the Ist week after birth and appear to pass through a phase of physiological undernutrition.

2. Twenty-three guinea-pigs belonging to ten litters were killed at birth and sixteen from seven litters were killed when they were I week old. The bodies and livers were analysed separately.

3. The following changes in the chemical composition of the body took place in the Ist week of life, $(a)$ a rise in the percentage of water, $(b)$ a fall in the percentage of fat, $(c)$ a fall in the nitrogen:potassium ratio.

4. The changes in the liver differed in some respects in that $(a)$ there was a large loss of weight, $(b)$ there was a decrease in the size of the individual liver cells and an increase in their number, $(c)$ the percentage of protein in the liver rose, $(d)$ the percentages of glycogen and fat fell, $(e)$ the percentage of sodium fell and of potassium rose, but not in proportion to the change in protein, and consequently $(f)$ the $\mathrm{N}: \mathrm{K}$ ratio rose.

\section{REFERENCES}

Amoroso, E. C., Goffin, A., Halley, G., Matthews, L. H. \& Mathews, D. J. (1951). f. Physiol. Ir3, $4 P$.

Darling, F. F. (1947). Natural History in the Highlands and Islands. London: Collins.

Dible, J. H. (1932). F. Path. Bact. 35, 45 I.

Dible, J. H. \& Libman, J. (1934). Ұ. Path. Bact. 38, 269.

Ferguson, N. L. (1954). Brit. F. Nutr. 8, 269.

Harrison, M. F. (1953a). Proc. roy. Sac. B, 141, 203.

Harrison, M. F. (1953 b). Biochem. F. 55, 204. 
Imrie, C. G. \& Graham, S. G. (1920). F. biol. Chem. 44, 243.

McCance, R. A. \& Widdowson, E. M. (1955). Cold Spr. Harb, Symp. Quant. Biol. 19, 155.

Monaghan, B. R. (1932). F. biol. Chem. 98, 2 I.

Ohta, S. (1940). F. Biochem., Tokyo, 31, 197.

Roderick, L. M., Harshfield, G. S. \& Hawn, M. C. (I937). \%. Amer. vet. med. Ass. 90, 4 r. (N.S. 43, 4I).

Sinclair, R. G. (1933). F. biol. Chem. roo, lxxxvii.

Spray, C. M. \& Widdowson, E. M. (195I). Brit. F. Nutr. 4, 332.

Wallace, L. R. (1948). I. agric. Sci. 38, 367.

Widdowson, E. M. (1950). Nature, Lond., 166, 626. 